Abraham Jesús Arzeta-Ríos, Diana Guerra-Ramírez, Benito Reyes-Trejo*,

Ma. Carmen Ybarra-Moncada and Holber Zuleta-Prada

\title{
Microwave heating effect on total phenolics and antioxidant activity of green and mature coconut water
}

https://doi.org/10.1515/ijfe-2019-0378

Received January 9, 2020; accepted September 14, 2020; published online September 28, 2020

\begin{abstract}
Coconut water (Cocos nucifera $\mathrm{L}$.) from fruits of two ripening stages (green and mature) was used to perform microwave heat treatments. Three different heating conditions with maximum temperatures of 70,80 and $90{ }^{\circ} \mathrm{C}$ were tested in three holding times $(0,2$ and $4 \mathrm{~min}$ ). The Total Phenolic Content (TPC) using the FolinCiocalteu method and ABTS radical scavenging capacity were evaluated for each combination of coconut fruit age, heating temperature and holding time. It was observed that green coconut water exhibited significant differences $(\mathrm{p}<0.05)$ compared to mature coconuts in terms of TPC (46.03 and $69.16 \mathrm{mg} \mathrm{GAE} / \mathrm{L}$, respectively) and ABTS radical scavenging capacity (422.31 and $549.1 \mu \mathrm{mol} \mathrm{TE} / \mathrm{L}$, respectively). An increase in TPC (up to 23\%) and antioxidant activity (up to 19\%) was also observed with increasing temperature in the range of $70-90{ }^{\circ} \mathrm{C}$. Green coconut water showed the largest increase in both TPC and antioxidant activity.
\end{abstract}

Keywords: alternative technology; antioxidant capacity; Cocos nucifera; nutraceutical potential.

*Corresponding author: Benito Reyes-Trejo, Laboratorio de Productos Naturales, Área de Química, Departamento de Preparatoria Agrícola, Universidad Autónoma Chapingo, 56230, Texcoco, Edo. México, Mexico, E-mail: benijovi@yahoo.com.mx. https://orcid.org/ 0000-0001-9330-2646

Abraham Jesús Arzeta-Ríos, Departamento de Ingeniería Agroindustrial, Universidad Autónoma Chapingo, 56230, Texcoco, Edo. México, Mexico; and Laboratorio de Productos Naturales, Área de Química, Departamento de Preparatoria Agrícola, Universidad Autónoma Chapingo, 56230, Texcoco, Edo. México, Mexico Diana Guerra-Ramírez and Holber Zuleta-Prada, and Laboratorio de Productos Naturales, Área de Química, Departamento de Preparatoria Agrícola, Universidad Autónoma Chapingo, 56230, Texcoco, Edo. México, Mexico

Ma. Carmen Ybarra-Moncada, Departamento de Ingeniería Agroindustrial, Universidad Autónoma Chapingo, 56230, Texcoco, Edo. México, Mexico

\section{Introduction}

The coconut, Cocos nucifera L. (Arecaceae), is a governing part of the littoral flora across the tropics. Coconut water consumption in the international market has increased continuously in recent years, having various traditional uses. Recently it has been described as a natural functional drink and as a sports drink [1]. The chemical composition of coconut water has been determined in various studies, focusing on tender fruits [2-5] and on different stages of fruit ripening [6].

The extraction of coconut water entails the rupture of the stable and sterile conditions that it had within the fruit [7]. This has led to the application of thermal treatments for sterilization and enzymatic inactivation. The effect of heat treatment in the composition, physicochemical properties and enzymatic inactivation kinetics of immature, mature and overly- mature coconuts has been studied [6]. However, the nutritional quality, the physicochemical, rheological and organoleptic properties of the processed products can be lost when traditional thermal techniques are used [8].

There are alternatives to coconut water processing that have different effects on quality. To preserve coconut water, the effect of a non-thermal two-stage microfiltration technique under aseptic conditions has been evaluated [9]. The effect of other techniques such as ohmic heating [10], high pressure carbon dioxide pasteurization [11, 12], ultraviolet radiation [13] and microwave heating [7] has also been evaluated. Most of these studies have focused on fresh coconut and have addressed the processes of inactivation of the enzymes Polyphenol oxidase and Peroxidase.

The effect of microwave heating and conventional heat treatments on antioxidant activity has been evaluated in juice concentrates [14], as well as green vegetables [15]. Kinetic evaluation of antioxidant capacity has been evaluated in York cabbage after a bleaching treatment [16] and microwave processing [17].

The phytochemical compounds and antioxidant activity in fresh coconut water have also been evaluated [18]. 
Specifically, the antioxidant activity has been little studied in coconut water of different stages of maturation. The evaluation of phenolic compounds before and after heat treatment has been carried out formerly [6]. However, there are no studies related to the antioxidant activity of coconut water using alternative processing techniques such as microfiltration, ohmic heating, ultraviolet radiation, etc. The aim of this work was to determine the stability of total phenolics and antioxidant activity in coconut water of two stages of maturity, through changes induced by microwave treatment.

\section{Materials and methods}

\subsection{Reagents}

Folin-Ciocalteu, 2,2-azinobis (3-ethyl-benzothiazoline-6-sulfonic acid) diammonium salt (ABTS) reagents, anhydrous sodium carbonate, 6-hydroxy-2,5,7,8-tetramethylchroman-2-carboxylic acid (Trolox) and gallic acid were purchased from Sigma Aldrich Co., St. Louis, USA.

\subsection{Plant material}

In this study, coconut fruits of two different stages of maturity were used. The fruit ages were 9 months (green) and 12 months (mature). All coconuts were harvested from the garden of a producer from Benito Juárez, Guerrero, Mexico. Coconut water was extracted manually with a special knife to pierce the fruit mesocarp. The water extracted from three coconuts of each age was used to perform the microwave heat treatment. Endosperm thickness was measured with a digital caliper, with an average of three different reading points. The volume of water was measured with a graduated cylinder. Total soluble solids (TSS) were expressed as Brix and measured with a digital hand refractometer (ATAGO, Japan). All determinations were made in triplicate.

\subsection{Microwave heat treatment}

The batch microwave heating process was carried out in a microwave system (CEM, mod. Discover system, USA, Matthews) at $2450 \mathrm{MHz}$ [7]. A glass tube was filled with $5 \mathrm{~mL}$ of coconut water. The glass tube was inserted vertically into the microwave digester cavity under continuous microwave incidence. Once the desired temperature and holding time were reached, the tube was quickly inserted into an ice water bath to accelerate cooling. Subsequently, aliquots were collected to determine total phenolics and the ABTS test. Three different heating conditions with maximum temperatures of 70,80 and $90^{\circ} \mathrm{C}$ were tested in three holding times ( 0,2 and $4 \mathrm{~min}$ ) for coconut water of two stages of fruit ripening.

\subsection{Antioxidant properties}

2.4.1 Total Phenolic Content: The Total Phenolic Content (TPC) of coconut water of two stages of maturation was determined using the
Folin-Ciocalteu method [19] adapted to microplates [20]. A stock solution of $500 \mathrm{mg} / \mathrm{L}$ gallic acid in deionized water was made to prepare a calibration curve in a concentration range of $1.25-11.25 \mu \mathrm{g} / \mathrm{mL}$. In the wells of a 96-well microplate $25 \mu \mathrm{L}$ of coconut water, $125 \mu \mathrm{L}$ of distilled water, $20 \mu \mathrm{L}$ of Folin-Ciocalteu reagent and $30 \mu \mathrm{L}$ of $20 \%$ sodium carbonate $\left(\mathrm{Na}_{2} \mathrm{CO}_{3}\right)$ were mixed. The mixture was reacted for $30 \mathrm{~min}$ under dark conditions. Each sample was processed in triplicate. After time, the absorbance reading was taken at a wavelength of $760 \mathrm{~nm}$ in a microplate reader (Synergy 2, BioTek, USA). The results were reported as milligram gallic acid equivalents per milliliter (mg GAE/L).

2.4.2 ABTS test: The ABTS (2,2-azinobis (3-ethyl-benzothiazoline6-sulfonic acid) diammonium salt) radical test was carried with some modifications [21]. For the preparation of the ABTS solution, equal volumes of two solutions (A and B) were mixed. Solution A consisted of $7.4 \mathrm{mM}$ ABTS and solution $B$ is $2.6 \mathrm{mM}$ sodium persulfate. After mixing both solutions, it was allowed to incubate at room temperature for $16 \mathrm{~h}$ in a dark place. After the incubation time, $600 \mu \mathrm{L}$ of the mixture was taken and titrated to $10 \mathrm{~mL}$ with pure methanol. A stock solution of Trolox at $250 \mathrm{mg} / \mathrm{L}$ (with $80 \%$ methanol) was prepared for the calibration curve. The dilutions of the Trolox stock solution for the calibration curve were prepared to give final concentrations in a range of 5-60 $\mu \mathrm{M}$. In a microplate, $20 \mu \mathrm{L}$ of the optimal coconut water or Trolox water solution and $180 \mu \mathrm{L}$ of ABTS were placed. The decrease in absorbance was recorded at $734 \mathrm{~nm}$ after $10 \mathrm{~min}$. With the data obtained, a Trolox calibration curve was generated. Based on the equation obtained, the $\mu \mathrm{mol}$ of sample equivalent to Trolox ( $\mu \mathrm{mol} \mathrm{TE} / \mathrm{L}$ ) was determined to capture the ABTS radical.

\subsection{Statistical analysis}

All experiments were performed in triplicate. SAS statistical software (SAS Institute Inc., 2019) was used. The results were reported as mean values \pm standard deviation and analyzed by analysis of variance. Comparisons of means were made using the HSD test with a significance of 0.05. Three-factor design was used to analyze the differences between coconut fruit ages, temperature and holding time.

\section{Results and discussion}

\subsection{Antioxidant properties}

\subsubsection{Total Phenolic Content (TPC)}

The Total Phenolic Content (TPC) is affected by the heat generated by the microwaves, microwave treatments consist of maintaining the power for a certain time, usually not longer than $15 \mathrm{~min}[7,17]$. The TPC of coconut water of different stages of maturation has been analyzed by different authors, however, the effect of microwave heating on the antioxidant activity of coconut water has not been described. The one-way ANOVA was carried out to analyze the differences between the characteristics of fresh coconut water of two stages. Table 1 shows the variation of the TPC 
Table 1: Characteristics of coconut fruits evaluated before microwave heating.

\begin{tabular}{|c|c|c|c|c|c|}
\hline Coconut age (months) & $\begin{array}{r}\text { Water volume } \\
(\mathrm{mL})\end{array}$ & $\begin{array}{r}\text { Soluble solids } \\
\text { ('Brix) }\end{array}$ & $\begin{array}{r}\text { Endosperm thickness } \\
(\mathrm{mm})\end{array}$ & TPC (mg GAE/L) & $\begin{array}{r}\text { ABTS radical scavenging } \\
\text { capacity }(\mu \mathrm{mol} \mathrm{TE} / \mathrm{L})\end{array}$ \\
\hline 9 & $523.33 \pm 25.17^{\mathrm{a}}$ & $6.40 \pm 0.10^{\mathrm{a}}$ & $5.67 \pm 0.58^{b}$ & $46.03 \pm 0.53^{b}$ & $422.31 \pm 21.62^{b}$ \\
\hline 12 & $403.33 \pm 20.82^{b}$ & $6.17 \pm 0.67^{a}$ & $13.33 \pm 0.58^{\mathrm{a}}$ & $69.16 \pm 1.33^{a}$ & $549.10 \pm 15.65^{a}$ \\
\hline
\end{tabular}

Mean \pm standard deviation values in a column with different letters are significantly different at $p<0.05$.

in coconut water of two stages of maturation ( 9 and 12 months). It is observed that the water of the green coconuts present significant differences compared to mature coconuts in terms of TPC (46.03 and $69.16 \mathrm{mg}$ GAE/L, respectively) and ABTS radical scavenging capacity (422.31 and $549.10 \mu \mathrm{mol} \mathrm{TE} / \mathrm{L}$, respectively). Water volume and endosperm thickness show significative difference between fruit age $(p<0.05)$. The thickness of the endosperm was greater in the mature coconut than in the green coconut, as stated in literature [22, 23]. The volume of coconut water is within the range (100-600 $\mathrm{mL}$ ) reported in the literature [4], being higher in green coconut water than in mature coconut water $[1,6]$. The measured volume of mature coconut water is slightly higher than that reported for tall varieties by other authors $[1,4]$. Total soluble solids content did not show statistically significant difference $(p=0.581)$ between green and mature coconut water, which is not consistent in the literature. This is due to the variety, region, and time of harvest [23]. In most coconut varieties the total soluble solids reduce as the fruit ripens $[6,24]$.

The treatment of green coconut water with microwaves at temperatures between 40 and $90{ }^{\circ} \mathrm{C}$ has been reported [7], based on measuring the temperature and not the microwave power by a certain time to determine the enzymatic activity. In addition, it has been reported a holding time of $0 \mathrm{~s}$ for all treatments, evaluating degradation kinetics of antioxidant compounds. In this study, the effect of microwave heating in two stages of coconut fruit maturation was assessed, considering three temperatures $(70,80$ and $90^{\circ} \mathrm{C}$ ) and three holding times (0, 2 and $\left.4 \mathrm{~min}\right)$. TPC and ABTS radical scavenging capacity were evaluated for each combination of coconut age, temperature and time. Table 2 shows a reduction of the TPC at temperatures between 70 and $80^{\circ} \mathrm{C}$. However, with the increase in heating temperature and holding time $\left(90^{\circ} \mathrm{C}, 4 \mathrm{~min}\right)$ an increase in the TPC is observed. So far, the increase in phenolic content in coconut water due to microwave heating has not been reported, however, in some fresh vegetables increase phenolic content due to heat treatment is attributed to the release of flavonols [15]. It can be observed that total phenol content in mature coconut water is higher than in green coconut water in all treatments tested. Although the mature
Table 2: Changes in the TPC of microwave-heated coconut water.

\begin{tabular}{|c|c|c|c|c|}
\hline $\begin{array}{l}\text { Coconut age } \\
\text { (months) }\end{array}$ & $\begin{array}{r}\text { Temperature } \\
\left({ }^{\circ} \mathrm{C}\right)\end{array}$ & $\begin{array}{r}\text { Holding time } \\
\text { (min) }\end{array}$ & TPC (mg GAE/L) & $\%^{1}$ \\
\hline \multirow[t]{9}{*}{9} & 70 & 0 & $45.69 \pm 2.54^{c}$ & 99 \\
\hline & & 2 & $40.50 \pm 4.59^{c}$ & 88 \\
\hline & & 4 & $40.23 \pm 5.43^{c}$ & 87 \\
\hline & 80 & 0 & $42.92 \pm 3.89^{c}$ & 93 \\
\hline & & 2 & $40.07 \pm 2.30^{c}$ & 87 \\
\hline & & 4 & $54.07 \pm 9.34^{\mathrm{ab}}$ & 117 \\
\hline & 90 & 0 & $51.72 \pm 4.85^{b c}$ & 112 \\
\hline & & 2 & $56.26 \pm 10.50^{\mathrm{ab}}$ & 122 \\
\hline & & 4 & $56.51 \pm 2.43^{\mathrm{ab}}$ & 123 \\
\hline \multirow[t]{9}{*}{12} & 70 & 0 & $62.10 \pm 5.78^{\mathrm{ab}}$ & 90 \\
\hline & & 2 & $60.58 \pm 2.48^{\mathrm{ab}}$ & 88 \\
\hline & & 4 & $57.75 \pm 2.99^{\mathrm{ab}}$ & 84 \\
\hline & 80 & 0 & $59.30 \pm 3.33^{\mathrm{ab}}$ & 86 \\
\hline & & 2 & $62.74 \pm 1.61^{a b}$ & 91 \\
\hline & & 4 & $61.73 \pm 1.90^{\mathrm{ab}}$ & 89 \\
\hline & 90 & 0 & $66.37 \pm 0.63^{a}$ & 96 \\
\hline & & 2 & $66.34 \pm 2.02^{\mathrm{a}}$ & 96 \\
\hline & & 4 & $66.81 \pm 0.80^{\mathrm{a}}$ & 97 \\
\hline
\end{tabular}

Mean \pm standard deviation values in a column with different letters are significantly different at $p<0.05$.

${ }^{1}$ Fresh $=100$.

coconut water suffered a reduction in the TPC, the disappearance of the significant difference between both coconut waters was not observed. It can be observed that microwave treatments effects on coconut water of two stages initially caused a reduction in the TPC and a subsequent increase in this parameter at temperatures above $80^{\circ} \mathrm{C}$.

Temperature has different effects on the TPC of food. It has been reported that phenolic compounds such as quercetin derivatives present a higher thermal stability, which causes phenolic compounds to increase [25]. The reduction of the TPC can also occur when food is cooked [26], which is attributed to the breakdown of phenolics [15]. The increase in temperature and holding time has a greater effect on the TPC of green coconut water, generating an increase of $23 \%$ respect to fresh coconut water, compared to mature coconut water (content less than $100 \%$ ). It can be observed that the greater effect of the treatments tested on the TPC (for both, green and mature coconut water) is 
mainly due to the increase in temperature and to a lesser extent to the holding time.

\subsubsection{ABTS test}

The effect of heat treatment on antioxidant capacity of vegetables has been determined by ABTS assay [25]. Microwave heat treatment of coconut water of different maturity stages was evaluated to determine the effect on the ABTS radical scavenging capacity. In Table 3 it can be seen that there is a significant difference $(p<0.05)$ between ABTS scavenging of green coconut water and mature coconut water. The response of green coconut water to microwave heat treatments was mainly a reduction of the ABTS scavenging $(<100 \%)$ over the entire range of evaluated temperatures, but not for mature coconut water, which showed an increase at $90^{\circ} \mathrm{C}(111 \%)$.

Heat treatments like boiling increase the antioxidant activity of vegetables [15]. It is documented that antioxidant potential after heat treatments has no change due to formation of novel or naturally occurring compounds [27]. Another reason is attributed to pro-oxidant activity reduction caused by the inactivation of peroxidases at high temperatures [28].

Table 3: Changes in ABTS radical scavenging capacity of microwave-heated coconut water.

\begin{tabular}{|c|c|c|c|c|}
\hline $\begin{array}{l}\text { Coconut age } \\
\text { (months) }\end{array}$ & $\begin{array}{r}\text { Temperature } \\
\left({ }^{\circ} \mathrm{C}\right)\end{array}$ & $\begin{array}{r}\text { Holding } \\
\text { time (min) }\end{array}$ & $\begin{array}{r}\text { ABTS radical } \\
\text { scavenging } \\
\text { capacity } \\
(\mu \mathrm{mol} \mathrm{TE} / \mathrm{L})\end{array}$ & $\%^{1}$ \\
\hline \multirow[t]{9}{*}{9} & 70 & 0 & $403.72 \pm 26.24^{c}$ & 96 \\
\hline & & 2 & $396.45 \pm 25.08^{c}$ & 94 \\
\hline & & 4 & $408.95 \pm 4.30^{c}$ & 97 \\
\hline & 80 & 0 & $383.95 \pm 33.97^{c}$ & 91 \\
\hline & & 2 & $405.11 \pm 40.31^{c}$ & 96 \\
\hline & & 4 & $434.17 \pm 25.44^{c}$ & 103 \\
\hline & 90 & 0 & $461.41 \pm 14.97^{b c}$ & 109 \\
\hline & & 2 & $491.00 \pm 40.22^{\mathrm{abc}}$ & 116 \\
\hline & & 4 & $503.29 \pm 41.48^{\mathrm{abc}}$ & 119 \\
\hline \multirow[t]{9}{*}{12} & 70 & 0 & $576.46 \pm 51.35^{\mathrm{ab}}$ & 105 \\
\hline & & 2 & $557.11 \pm 69.08^{\mathrm{ab}}$ & 101 \\
\hline & & 4 & $581.28 \pm 20.91^{\mathrm{ab}}$ & 106 \\
\hline & 80 & 0 & $559.47 \pm 80.00^{\mathrm{ab}}$ & 102 \\
\hline & & 2 & $562.65 \pm 76.10^{\mathrm{ab}}$ & 102 \\
\hline & & 4 & $558.56 \pm 70.32^{\mathrm{ab}}$ & 102 \\
\hline & 90 & 0 & $612.99 \pm 19.86^{\mathrm{a}}$ & 112 \\
\hline & & 2 & $594.73 \pm 29.76^{\mathrm{ab}}$ & 108 \\
\hline & & 4 & $610.63 \pm 25.35^{a}$ & 111 \\
\hline
\end{tabular}

Mean \pm standard deviation values in a column with different letters are significantly different at $\mathrm{p}<0.05$.

${ }^{1}$ Fresh $=100$.
The antioxidant capacity of 12-month coconut water before microwave heating (fresh) is significantly $(p<0.05)$ higher than that of 9-month coconut water (549.10 and $422.31 \mu \mathrm{mol} \mathrm{TE} / \mathrm{L}$, respectively). For 12-month coconut water (processed), $70^{\circ} \mathrm{C}$ and $0 \mathrm{~min}$, there were $576.46 \mu \mathrm{mol}$ $\mathrm{TE} / \mathrm{L}$, while for $90^{\circ} \mathrm{C}$ and $4 \mathrm{~min}, 610.63 \mu \mathrm{mol} \mathrm{TE} / \mathrm{L}$ were quantified (a significant increase, $\mathrm{p}<0.05$ ). In addition, for 9-month-old coconut water processed at $70^{\circ} \mathrm{C}$ and $0 \mathrm{~min}$, there were $403.72 \mu \mathrm{mol} \mathrm{TE} / \mathrm{L}$, whereas for $90^{\circ} \mathrm{C}$ and $4 \mathrm{~min}$, $503.29 \mu \mathrm{mol} \mathrm{TE} / \mathrm{L}$ were determined (a significant increase, $\mathrm{p}<0.05)$. The effect of temperature on the antioxidant capacity of green coconut water $(96-119 \%)$ is more noticeable than in mature coconut water (105-111\%). In green coconut water, the increase in ABTS scavenging was $422 \mu \mathrm{mol} \mathrm{TE} / \mathrm{L}$ (fresh) to $503 \mu \mathrm{mol} \mathrm{TE} / \mathrm{L}$ (microwave treated at $90{ }^{\circ} \mathrm{C}$ and holding time of $4 \mathrm{~min}$ ). Mature coconut water showed no significant difference $(\mathrm{p}<0.05)$ in antioxidant capacity with microwave heat treatments (temperature and holding time combinations).

\subsection{Statistical analysis}

Three-factor ANOVA was performed for the treatment of coconut water by microwave heating at fixed temperatures with variable time (0-4 $\mathrm{min})$. For cases where the working temperature was less than $90^{\circ} \mathrm{C}$, no statistically significant difference $(\alpha=0.05)$ was found in the TPC of mature coconut water during the microwave processing time. Table 4 shows that coconut fruit age is a variable that generates significant differences in the TPC, as reported in the literature [6]. The total phenolic content in green coconut water (9 months) is lower than that found in mature coconut water (12 months).

Microwave heating temperature has a significant effect in TPC of coconut water $(\mathrm{p}<0.05)$. Evaluated times do not have a significant effect on the TPC $(p=0.465)$. Only the interaction between time and temperature was significant for the TPC $(p<0.05)$. This suggests the evaluation of higher temperatures and longer holding times in order to evaluate the effect that a severe heat treatment would have on the TPC.

The significative factors of microwave heating in ABTS scavenging capacity of coconut water are shown in Table 5. Again, it is observed that coconut age is a factor for significative differences in ABTS scavenging capacity. Temperature has a significant effect on antioxidant activity. In this case, interaction between Temperature $\times$ Time has no significant effect on ABTS scavenging capacity.

The determination of TPC using the Folin-Ciocalteu method is affected by interfering substances (aromatic 
Table 4: Three-factor ANOVA for TPC of two maturity stages of coconut water heated by microwave.

\begin{tabular}{|c|c|c|c|c|c|}
\hline Source & DF & Sum of squares & Mean square & F-Value & p-Value \\
\hline Age & 1 & 3071.18 & 3071.18 & 147.42 & $<0.0001$ \\
\hline Temperature & 2 & 887.57 & 443.79 & 21.3 & $<0.0001$ \\
\hline Time & 2 & 32.62 & 16.31 & 0.78 & 0.465 \\
\hline Age $*$ Temperature & 2 & 91.52 & 45.76 & 2.2 & 0.126 \\
\hline Age $*$ Time & 2 & 78.96 & 39.48 & 1.89 & 0.165 \\
\hline Temperature $*$ Time & 4 & 243.4 & 60.85 & 2.92 & 0.034 \\
\hline Age $*$ Temperature $*$ Time & 4 & 122.04 & 30.51 & 1.46 & 0.233 \\
\hline Error & 36 & 750.01 & 20.83 & & \\
\hline Total & 53 & 5277.3 & & & \\
\hline
\end{tabular}

Table 5: Three-factor ANOVA for ABTS scavenging capacity of two maturity stages of coconut water heated by microwave.

\begin{tabular}{|c|c|c|c|c|c|}
\hline Source & DF & Sum of squares & Mean square & F-Value & p-Value \\
\hline Age & 1 & 292971 & 292971 & 149.69 & $<0.0001$ \\
\hline Temperature & 2 & 43330 & 21665 & 11.07 & $<0.0001$ \\
\hline Time & 2 & 2988 & 1494 & 0.76 & 0.474 \\
\hline Age $*$ Temperature & 2 & 5298 & 2649 & 1.35 & 0.271 \\
\hline Age $*$ Time & 2 & 2594 & 1297 & 0.66 & 0.522 \\
\hline Temperature $*$ Time & 4 & 1155 & 289 & 0.15 & 0.963 \\
\hline Age $*$ Temperature $*$ Time & 4 & 1695 & 424 & 0.22 & 0.928 \\
\hline Error & 36 & 70459 & 1957 & & \\
\hline Total & 53 & 420491 & & & \\
\hline
\end{tabular}

amines, $\mathrm{Fe}^{\mathrm{II}}$, among others), and can lead to a detection of a greater number of compounds, whereas the ABTS radical is neutralized by antioxidants with a lower redox potential, which makes it a more specific technique [29]. As a result, the temperature * time interaction was significant $(\mathrm{p}<0.05)$ for TPC, but not for ABTS.

\section{Conclusion}

The effect of microwave heating on the concentration of phenolic compounds and antioxidant activity of green and mature coconut water has been evaluated. The 9-month coconut water before microwave heating had lower ( $\mathrm{p}<0.05$ ) TPC and ABTS (46.03 GAE/L and $422.31 \mu \mathrm{mol} \mathrm{TE} /$ $\mathrm{L}$, respectively) than that of 12 -month coconut water without process $(69.16 \mathrm{mg} \mathrm{GAE} / \mathrm{L}$ and $549.10 \mu \mathrm{mol} \mathrm{TE} / \mathrm{L}$, respectively). The most drastic treatment $\left(90^{\circ} \mathrm{C}, 4 \mathrm{~min}\right)$ increased the TPC of both green and mature coconut water (56.51 mg GAE/L and 66.81 mg GAE/L, respectively). There was also an increase in ABTS radical scavenging capacity in both green and mature coconut water (503.29 $\mu \mathrm{mol} \mathrm{TE} / \mathrm{L}$ and $610.63 \mu \mathrm{mol} \mathrm{TE} / \mathrm{L}$, respectively). The increase in temperature is the factor that most affects the concentration of TPC and antioxidant activity. It should also be noted that differences in temperature ${ }^{\star}$ time interactions for TPC and ABTS were due to the specificity of the methods. Phenolic compounds and antioxidant activity in coconut water are stable at high processing temperatures $\left(90^{\circ} \mathrm{C}\right)$ and holding times of up to $4 \mathrm{~min}$, even an increase in these parameters has been observed (23 and 19\% for TPC and antioxidant activity respectively). According to the statistical analysis, there are no significant differences in the concentration of total phenolics and antioxidant activity of coconut water during processing time at temperatures below $80^{\circ} \mathrm{C}$.

Acknowledgments: We are grateful to CONACyT Mexico for stimulating support.

Author contribution: All the authors have accepted responsibility for the entire content of this submitted manuscript and approved submission.

Research funding: None declared.

Conflict of interest statement: The authors declare no conflicts of interest regarding this article.

\section{References}

1. Prades A, Dornier M, Diop N, Pain J-P. Coconut water uses, composition and properties: a review. Fruits 2012;67:87-107. 
2. Chidambaram S, Singaraja C, Prasanna MV, Ganesan M, Sundararajan M. Chemistry of tender coconut water from the Cuddalore coastal region in Tamil Nadu, India. Nat Resour Res 2013;22:91-101.

3. Yong JWH, Ge L, Ng YF, Tan SN. The chemical composition and biological properties of coconut (Cocos nucifera L.) water. Molecules 2009;14:5144.

4. Campos CF, Souza PEA, Coelho JV, Glória MBA. Chemical composition, enzyme activity and effect of enzyme inactivation on flavor quality of green coconut water. J Food Process Preserv 1996;20:487-500.

5. Maciel MI, Oliveira SL, Da Silva IP. Effects of different storage conditions on preservation of coconut (Cocos nucifera) water. J Food Process Preserv 1992;16:13-22.

6. Tan T-C, Cheng L-H, Bhat R, Rusul G, Easa AM. Composition, physicochemical properties and thermal inactivation kinetics of polyphenol oxidase and peroxidase from coconut (Cocos nucifera) water obtained from immature, mature and overlymature coconut. Food Chem 2014;142:121-8.

7. Matsui KN, Gut JAW, de Oliveira PV, Tadini CC. Inactivation kinetics of polyphenol oxidase and peroxidase in green coconut water by microwave processing. J Food Eng 2008;88: 169-76.

8. Jiménez-Sánchez C, Lozano-Sánchez J, Segura-Carretero A, Fernández-Gutiérrez A. Alternatives to conventional thermal treatments in fruit-juice processing. Part 2: effect on composition, phytochemical content, and physicochemical, rheological, and organoleptic properties of fruit juices. Crit Rev Food Sci Nutr 2017;57:637-52.

9. Mahnot NK, Kalita D, Mahanta CL, Chaudhuri MK. Effect of additives on the quality of tender coconut water processed by nonthermal two stage microfiltration technique. LWT - Food Sci Technol (Lebensmittel-Wissenschaft -Technol) 2014;59: 1191-5.

10. Delfiya DSA, Thangavel K. Effect of ohmic heating on polyphenol oxidase activity, electrical and physicochemical properties of fresh tender coconut water. Int J Food Eng 2016;12:691-700.

11. De Marchi F, Aprea E, Endrizzi I, Charles M, Betta E, Corollaro ML, et al. Effects of pasteurization on volatile compounds and sensory properties of coconut (Cocos nucifera L.) water: thermal vs. Highpressure carbon dioxide pasteurization. Food Bioprocess Technol 2015;8:1393-404.

12. Cappelletti M, Ferrentino G, Endrizzi I, Aprea E, Betta E, Corollaro ML, et al. High Pressure Carbon Dioxide pasteurization of coconut water: a sport drink with high nutritional and sensory quality. J Food Eng 2015;145:73-81.

13. Augusto PED, Ibarz R, Garvín A, Ibarz A. Peroxidase (POD) and polyphenol oxidase (PPO) photo-inactivation in a coconut water model solution using ultraviolet (UV). Food Res Int 2015;74:151-9.

14. Yousefi S, Emam-Djomeh Z, Mousavi SMA, Askari GR. Comparing the effects of microwave and conventional heating methods on the evaporation rate and quality attributes of pomegranate (Punica granatum L.) juice concentrate. Food Bioprocess Technol 2012;5:1328-39.
15. Turkmen N, Sari F, Velioglu YS. The effect of cooking methods on total phenolics and antioxidant activity of selected green vegetables. Food Chem 2005;93:713-8.

16. Jaiswal AK, Gupta S, Abu-Ghannam N. Kinetic evaluation of colour, texture, polyphenols and antioxidant capacity of Irish York cabbage after blanching treatment. Food Chem 2012;131: 63-72.

17. Jaiswal AK, Abu-Ghannam N. Degradation kinetic modelling of color, texture, polyphenols and antioxidant capacity of York cabbage after microwave processing. Food Res Int 2013;53: 125-33.

18. Akpro LA, Gbogouri GA, Konan BR, Issali AE, Konan KJL, Brou KD, et al. Phytochemical compounds, antioxidant activity and nonenzymatic browning of sugars extracted from the water of immature coconut (Cocos nucifera L.). Sci African 2019:e00123. https://doi.org/10.1016/j.sciaf.2019.e00123.

19. Singleton VL, Rossi JA. Colorimetry of total phenolics with phosphomolybdic-phosphotungstic acid reagents. Am J Enol Vitic 1965;16:144-58.

20. Hernández-Rodríguez G, Espinosa-Solares T, Hernández-Eugenio G, Villa-García M, Reyes-Trejo B, Guerra-Ramírez D. Influence of polar solutions on the extraction of phenolic compounds from capulín fruits (Prunus serotina). J Mex Chem Soc 2016;60:73-8.

21. Re R, Pellegrini N, Proteggente A, Pannala A, Yang M, Rice-Evans C. Antioxidant activity applying an improved ABTS radical cation decolorization assay. Free Radic Biol Med 1999;26:1231-7.

22. Hahn F. An on-line detector for efficiently sorting coconut water at four stages of maturity. Biosyst Eng 2012;111:49-56.

23. Siriphanich J, Saradhuldhat P, Romphophak T, Krisanapook K, Pathaveerat S, Tongchitpakdee S. 2 - coconut (Cocos nucifera L.). In: EMBT-PB Yahia, editor Woodhead Publishing Series in Food Science, Technology and Nutrition Woodhead Publishing; 2011; 8-35e pp. T of T and SF.

24. Halim HH, Williams Dee E, Pak Dek MS, Hamid AA, Ngalim A, Saari $\mathrm{N}$, et al. Ergogenic attributes of young and mature coconut (Cocos nucifera L.) water based on physical properties, sugars and electrolytes contents. Int J Food Prop 2018;21:2378-89.

25. Juániz I, Ludwig IA, Huarte E, Pereira-Caro G, Moreno-Rojas JM, Cid C, et al. Influence of heat treatment on antioxidant capacity and (poly)phenolic compounds of selected vegetables. Food Chem 2016;197:466-73.

26. Sahlin E, Savage GP, Lister CE. Investigation of the antioxidant properties of tomatoes after processing. J Food Compos Anal 2004;17:635-47.

27. Manzocco L, Calligaris S, Mastrocola D, Nicoli MC, Lerici CR. Review of non-enzymatic browning and antioxidant capacity in processed foods. Trends Food Sci Technol 2000;11:340-6.

28. Gazzani G, Papetti A, Massolini G, Daglia M. Anti- and prooxidant activity of water soluble components of some common diet vegetables and the effect of thermal treatment. J Agric Food Chem 1998;46:4118-22.

29. Prior RL, Wu X, Schaich K. Standardized methods for the determination of antioxidant capacity and phenolics in foods and dietary supplements. J Agric Food Chem 2005;53:4290-302. 